\title{
Social Workers as Senior Executives: Does Academic Training Dictate Leadership Style?
}

\author{
Lauri Goldkind \\ Manoj Pardasani
}

\begin{abstract}
The range and patterns of leadership styles in human service organizations are important for social work educators and their students to understand if social work administrators are to compete successfully in the marketplace for executive director and other top management roles. Using a sample of executive directors of human service organizations located in a state in the Northeast section of the U.S., the Multifactor Leadership Questionnaire (MLQ) was used to explore their leadership style. The authors compare various elements of leadership style (charisma, inter-personal transactions, reactions to work issues, etc.) as well as perceptions of effectiveness and satisfaction with leadership style across academic backgrounds of executive directors. These results highlight the competencies required of successful leaders and can assist educators in identifying curricular gaps developing courses preparing social workers for leadership positions in the field. This study provides critical information on the core leadership skills and knowledge relevant for effective social work administration. Implications for social work training and education are discussed as well as possible avenues for curriculum revision.
\end{abstract}

Keywords: Leadership style, executive director, Multifactor Leadership Questionnaire, social work administrator

The nonprofit sector is a critical component of the U.S. economy. In 2010, the Bureau of Economic Analysis reported over 1.5 million tax exempt organizations including nearly 1 million public charities. These organizations represent 9 percent of all wages and salaries paid in the U.S. as well as over 5 percent of the overall GDP of the United States economy (Sherlock \& Gravelle, 2009). This figure includes a diverse group of organizations, both in size and mission, which range from hospitals and human service organizations to advocacy groups and economic development corporations. According to Roeger, Blackwood and Pettijohn (2011), human service organizations accounted for approximately one-third of all organizations in the public charities category, making it the largest segment in the nonprofit sector. Similar to the growth of the non-profit sector, social work has been recognized as one of the fastest growing careers in the United States, with over 600,000 people holding social work degrees (National Association of Social Workers [NASW], 2009).

Despite the significant expansion of the nonprofit sector and the social work profession, the field of social work administration has not followed suit. Very few students in graduate social work programs express an interest in preparing for careers in

Lauri Goldkind, LMSW, Ph.D., is an Assistant Professor and Manoj Pardasani, LCSW, ACSW, Ph.D., is an Associate Professor, both in the Graduate School of Social Service at Fordham University in New York. The authors wish to thank the Office of Research at Fordham University for providing funding which supported this research.

Copyright @ 2013 Advances in Social Work Vol. 14 No. 2 (Fall 2013), 573-593 
administration; a large majority of students select clinical or interpersonal work as their practice focus (Wilson \& Lau, 2011; Wuenschel, 2006). This has created a serious scenario: on one hand many nonprofit social service administration jobs are filled by individuals with no social work background, while in parallel fewer social workers are being prepared for leadership positions in organizations.

A 2003 study by the United Way of New York City suggested a looming crisis in nonprofit management, with many nonprofit leaders on the verge of retirement and few potential leaders poised to take their place (Birdsell \& Muzzio, 2003). Despite the overwhelming need, few organizations reported that they were investing in the leadership training of their management staff (Birdsell \& Muzzio, 2003). Similarly, Austin, Regan, Samples, Schwartz, and Carnochan (2011) suggest that leadership training for non-profit administrators is limited in the practice arena, and scholarship evaluating and documenting such efforts is equally scarce. As a growing number of social service agencies are being run by administrators from fields other than social work, educational programs and professional groups like the National Association of Social Workers (NASW) and the National Network of Social Work Managers are concerned about the ability of social work to remain at the forefront of agency decision-making and the development of policy at the highest levels (Ezell, Chernesky, \& Healy, 2004).

For more than three decades, some social work educators have recognized the unique challenges of training social work administrators and the limitations of schools of social work in preparing students as administrators (Ezell, Chernesky, \& Healy 2004; Neugeboren, 1986; Patti, 1987; Wuenschel, 2006). One of the reasons for this is the absence of a conceptualization and the documentation of specific competencies that are essential for administrative practice (Edwards, Cooke, \& Reid, 1996; McNutt, 1995; Menefee, 2009; Wimpfheimer, 2004). Another is uncertainty around the unique knowledge base and skills required to be effective managers and organizational leaders. It is imperative, therefore, to assess the specific competencies and knowledge-base required by service administrators and managers in the field, highlight the essential differences between administrators/managers trained in social work and those trained in other disciplines (such as law, business, public health, etc.), and evaluate the impact of specific leadership training on competencies needed in the field.

\section{Literature Review}

In the last two decades administrators with a social work background have faced significant challenges. While human services leadership jobs at the most senior levels have increasingly been filled with lawyers, economists, and MBAs, enrollments in social work administration and organizational leadership programs has been falling (Ezell et al., 2004; Hoefer, 2003). Social workers appear to be missing from leadership roles even in agencies that have unique social work traditions such as settlement houses. A review of the 37 member agencies of the United Neighborhood Houses of New York City reveals that only $30 \%$ of settlement house leaders hold an MSW degree (United Neighborhood Houses, 2012). If schools of social work are to remain viable vehicles for the training and professional development of social work leaders and managers they must focus on competency development that these social workers will need to be successful in 
leadership and senior management roles. In order to begin to understand the present leadership landscape in non-profit human services organizations the following sections explore recent scholarship on leader's demographic characteristics, social work education's specific focus on leadership training, and the main themes of the "Full Range Leadership Model” (FRLM) posited by Avolio and Bass (Antonakis, Avolio, \& Sivasubramaniam, 2003).

\section{Race, Gender, and Academic Credentials in the Executive Office}

Despite rapidly changing racial and ethnic characteristics in the United States, human services executive leadership remains dominated by whites. This is true both in agencies' governance structures, where boards of directors are comprised of predominately white males, and among executive directors. A national survey of nonprofit executives found that 82 percent of executive directors were white, 7 percent were African American, 4 percent were Asian-Pacific Islander, 4 percent were Latino/a, 0.7 percent were Native American, 0.4 percent were Middle Eastern, and 2 percent were "other"(Cornelius, Moyers, \& Bell, 2011).

In all geographic areas studied, the percentage of executive directors who were white exceeded the share of whites in the population. For example, in the San Francisco Bay area, $78 \%$ of executive directors were white compared with $58 \%$ of the population; in Sacramento, $91 \%$ of executive directors were white compared with $48 \%$ of the population (Bell, Moyers, \& Wolfred, 2006). It is also more likely for people of color to be an organization's primary clientele than it is for them to be the organization's executive director or deputy directors; even in organizations that serve primarily people of color, the executive leadership tends not to be of color (Teegarden, 2004).

Human service agencies appear prepared to embrace women leaders. A national survey of nonprofit executives found that the normative nonprofit executive director is a white woman in her 50s with about six years of experience as an administrator (Teegarden, 2004). While it is promising that women in the nonprofit arena have made inroads into executive management, Teegarden (2004) also found that female-led organizations were smaller than those led by men. Similar trends were identified in the budgets of such organizations; the median budget for female-led organizations was $\$ 500,000$ to $\$ 1$ million, while for men the median budget was $\$ 1$ million to $\$ 2$ million (Gose, 2004; Hrywna, 2006; O’Leary, 2009; Teegarden, 2004). Moreover, income disparity still exists between men and women agency leaders. On average, women earn less than men, with average salaries between $\$ 60,000$ to $\$ 69,999$ compared to men's \$70,000 to \$79,999 (Joslyn, 2003; Lipman, 2006; Teegarden, 2004).

While race and sex characteristics of nonprofit leaders are well-documented in the literature, academic credentials of senior leaders and their impact on agency operations, structures, and services remains a less examined area (Hoefer, 2003; Nesoff, 2007). Given the discourse in the field about social workers losing ground as human service agency executives, it is surprising that more empirical work has not been completed in this area. As Suarez (2010) notes, "nonprofit leaders must be credible with clients, donors, and staff" (p. 6), but there is nothing to say that the skills that lead to credibility 
must be procured in any single academic discipline. In his study of 200 nonprofit leaders, Suarez (2010) found that approximately 51\% held advanced academic credentials. Thirteen percent held degrees directly related to management, and $43 \%$ held advanced degrees in other applied disciplines, including five (2.5 percent) with MSWs (Suarez, 2010).

\section{Leadership Training for Social Workers}

Recent social work management literature has discussed the need for an "integration" of social work values with management skill and expertise (Richardson, 2010). In 2010, the Social Work Congress convened over 400 social work leaders for the purpose of defining social work "imperatives" to promote the advancement of the profession in the next decade. Among the ten imperatives was a call for leadership development to "integrate leadership training in social work curricula at all levels" (Social Work Congress, 2010). Achieving the integration of social work values and effective management skills may call for a restructuring of how social work educators prepare the next generation of leaders in the field.

At the same time scholars have acknowledged the possible inadequacies of leadership and management training at the MSW level, since 1987 the number of social work students specializing in administration has been declining steadily (Ezell et al., 2004). Approximately $80 \%$ of MSW graduates report a primary interest in direct or clinical practice (Austin \& Ezell, 2004). Only 3\% of graduate social work students specialize in administration in their academic programs (Wuenschel, 2006), suggesting that many social work students have extremely limited exposure to administrative and leadership activities during their professional education. The landscape of professional social work education also reflects these circumstances. The Council on Social Work Education's website lists a total of 68 accredited Masters of Social Work programs offering an administration or management concentration, and over 130 programs offering a clinical or direct practice oriented program. Thus, while many students may not come to advanced social work education with administration in mind, the limited number of programs that even offer such a concentration ensures that many students cannot even be exposed to this content even if they are interested in it.

When thinking about possible gaps in leadership and management training at the MSW level, it is worth noting that "many current human service managers began their careers as direct service workers and bring a more micro perspective into what, by definition, is a macro-oriented job" (Hopkins \& Hyde, 2002, p. 12). The presence of unplanned transitions from direct service worker to manager bolsters the argument for social work educators to seek opportunities to nurture and enhance the administrative inclinations and abilities of social work students and their exposure to the theories, skills, and techniques of leadership (Ezell et al., 2004; Long \& Shobe, 2010; Nesoff, 2007).

MSWs transitioning into leadership roles should have had at least some exposure to administrative thinking and management strategies. Knee and Folsom (2012) identify five skills commonly focused on in foundation year curricula and provide examples of how more explicit connections could be made to a management practice. Building on the 
work of earlier social work scholars, they argue that the foundational skills of communication, supervision, facilitation, teaming, and interpersonal skills, which are all hallmarks of social workers ability to relate and connect to people and communities, can be capitalized on in the management arena (Knee \& Folsom, 2012).

Those who design social work curricula need to understand the reasons human service agencies are hiring leaders from non-social work backgrounds. Do these disciplines provide knowledge or skills that are critical to leadership? If so, what specifically is this content? Can it be provided in the social work curriculum?

\section{The Full Range of Leadership Model}

The Full Range of Leadership Model (FRLM) posited by Bass and Avolio (1994) describes leadership behaviors and characteristics on a continuum from transformational to transactional, a third type of leadership described by the model is laissez-faire leadership. Building on the work of James Macgregor Burns who first introduced the concept of transformational leadership in 1978, Bass and Avolio (1994) not only refined the concept of transformational leadership but also suggested ways to measure it. The central argument of the FRLM is that a transformational leader assists individuals in uniting for a collective purpose and a vision for the future (Bass \& Avolio, 1994). They further define four distinct qualities of the transformational leader: charisma, intellectual stimulation, individual consideration, and inspirational motivation. According to the authors, better leaders are transformational more frequently; lesser leaders are passive or focus on corrective action (Bass \& Avolio, 1994).

In contrast to the intellectually engaging affective and charismatic qualities of transformational leadership, transactional leadership has been characterized as a contractual or exchange process between leaders and followers (Jung \& Avolio, 2000). Transactional leaders focus on the role of supervision, performance, and building organizational structures. The transactional leader identifies staff's expectations and provides rewards in exchange for high performance (Bass, 1985; Daft, 1999) - there is no concerted effort to change followers' personal values, nor necessarily a need to develop a deep sense of trust and commitment to the leader. Instead, the transactional leader works with followers' current needs and tries to satisfy those needs with desired outcomes once agreed upon performance levels are achieved.

Where transformational leadership is viewed as influential and inspirational and transactional leadership is goal oriented, laissez-faire leadership leaves decisions unmade, authority un-consulted, and responsibilities un-noticed (Khan, Aslam, \& Riaz, 2012). Laissez-faire leadership may be thought of as an absence of or avoidance of leadership (Bass \& Avolio, 1990, 1993, Bass, Avolio, \& Atwater, 1996).

Transformational leadership has emerged as a focus of study in social work leadership literature. Research has found that social service agency employees respond more favorably to transformational leaders than to transactional leaders (Gellis, 2001; Mizrahi \& Berger, 2005). Additionally, recent studies have noted transformational leadership's natural fit with the values of the social work profession (Mary, 2005; Mizrahi \& Berger, 2005; Richardson, 2010). 


\section{Study Questions}

This article reports on the results of an empirical study investigating the possible relationship between leadership style and academic background among administrators in the human services field. The authors surveyed over 1,600 human service agency administrators, managers, and leaders in a large Northeastern State.

This exploratory study sought to address two primary questions:

1. What, if any, patterns exist between demographic characteristics and leadership styles of human service agency administrators?

2. Are there essential leadership style differences between administrators from social work backgrounds and those from other academic disciplines?

\section{Methods}

The authors utilized a survey design to reach human services administrators in a large Northeastern State. The National Taxonomy of Exempt Entities (NTEE) system is used by the IRS and the National Center for Charitable Statistics (NCCS) to classify nonprofit organizations (NCCS, 2011). This study identified human service organizations by their NTEE codes. All organizations with an NTEE code of P (Human Services) were included in the sample. Cover letters and paper survey instruments were mailed to over 1,600 executive directors of category $\mathrm{P}$ - human services providers as identified by the National Taxonomy of Exempt Entities. Due to budgetary constraints for this project, follow-up mailings, which might have increased the response rate, were not possible. Surveys were returned anonymously; agency leaders did not submit their names or the names of their organizations.

The letter to agency executives invited them to participate in a study exploring the possible relationships between leadership styles and demographic characteristics of social service agency administrators in the tri-state region. The letter also introduced the principal investigators as current faculty members and former agency administrators with a personal interest in the subject matter of the study. The invitation letter also laid out the objectives of the study for the prospective participants. This research was conducted with Institutional Review Board approval from the authors’ university.

\section{Sample}

A total of 393 completed surveys were returned for a response rate of 23 percent. Table 1 describes the sample's characteristics. The majority (61.6\%) of the respondents were female while the rest were male (38.4\%). More than three-fourths of the respondents were Caucasian (85.8\%), while only 8.7\% were African American and less than $4 \%$ were either Latino (3.6\%) or Asian (2.0\%).

Nearly half of the administrators (48.7\%) reported more than 20 years of experience as a supervisor, while an additional one-third (33.7\%) reported between 11 and 20 years of experience. About one-third of the administrators had an MSW (35.9\%), while more than a quarter (29.8\%) had a master's degree in arts or social sciences. About the same 
number of respondents had only an undergraduate degree $(13.8 \%)$ or a doctoral degree (13.0\%).

Table 1. Demographic Characteristics of the Respondents

\begin{tabular}{lr}
\hline Demographic Characteristics & Percent \\
\hline Gender & 38.4 \\
Male & 61.6 \\
Female & \\
Age & 6.0 \\
$26-35$ & 14.5 \\
36-45 & 33.2 \\
46-55 & 46.4 \\
56 and older & \\
& \\
Race/Ethnicity & 8.7 \\
African American & 3.6 \\
Latino/Latina & 2.0 \\
Asian American & 85.8 \\
Caucasian American & \\
Educational Background & 13.8 \\
BA/BS & 29.8 \\
MA/MS & 35.9 \\
MSW & 3.9 \\
MBA & 3.6 \\
JD & 13.0 \\
PhD & \\
Years as Supervisor & 17.6 \\
10 years or less & 33.7 \\
More years than 20 years & 48.7 \\
& \\
\hline
\end{tabular}

\section{Instrument}

This study included the Multifactor Leadership Questionnaire (MLQ) to assess leadership styles of administrators of social service agencies. The MLQ measures leadership behavior as articulated by the FRLM (Full Range Leadership Model) posited by Bass and Avolio (2000). The FRLM is a leadership typology system with three distinct types of behavior: transformational, transactional, and non-transactional laissezfaire leadership. These types of leadership are represented by nine factors: idealized influence (attributed), idealized influence (behavior), inspirational motivation, intellectual stimulation, individual consideration, contingent reward, management by exception (active), management by exception (passive) and laissez-fairre leadership (Hunt, 1999; 
Lowe, Kroeck, \& Sivasubramaniam,1996; Yukl, 1999). The nine factors are grouped into six domains of leadership, including:

Charisma/Inspirational - Provides followers with a clear sense of purpose that is energizing; a role model for ethical conduct which builds identification with the leader and his/her articulated vision. This factor (style) comprises idealized influence (both attributed and behavior) and inspirational motivation.

Intellectual Stimulation - Gets followers to question the tried and true ways of solving problems; encourages them to question the methods they use to improve upon them.

Individualized Consideration - Focuses on understanding the needs of each follower and works continuously to get them to develop to their full potential.

Contingent Reward - Clarifies what is expected from followers and what they will receive if they meet expected levels of performance.

Active Management-by-Exception - Focuses on monitoring task execution for any problems that might arise and correcting those problems to maintain current performance levels.

Passive Avoidant - Tends to react only after problems have become serious to take corrective action and may avoid making any decisions at all. This factor comprises management by exception (passive) and laissez-faire leadership styles.

Reliability and validity of the MLQ 5X instrument were established by Bass and Avolio (2000), who report reliabilities ranging from .74 to .91. They also documented the construct validation process associated with the MLQ 5X. An early version of the scale was evaluated by an expert panel, and their recommendations were included in the final instrument development, which helped to ensure content validity. Since its initial development, 14 samples have been used to validate and cross-validate the MLQ Form 5X (Bass \& Avolio, 2000).

The 45-item instrument (MLQ) utilized in this study comprised six characteristic leadership categories (measured through nine sub-scales) and three self-perception of outcome scales (extra effort by administrators, perception of effectiveness as administrators, and satisfaction with leadership). The six characteristic leadership categories are further collapsed into three components - transformational leadership (comprising charisma, intellectual stimulation and individual consideration), active transactional leadership, and passive transactional leadership. Additionally, the MLQ also contains items that evaluate the administrators' self-perception of engaging in extra efforts as a leader, perception of effectiveness as a leader, and personal satisfaction with one's leadership.

Each item on the MLQ was assessed on a Likert scale ranging from 0 (not at all) to 4 (frequently, if not always). Figure 1 associates sample questions with the leadership style they are measuring. Reliability testing of the scales in this study yielded Cronbach alphas of 0.866 (transformational leadership), 0.753 (active transactional leadership), 0.811 
(passive transactional leadership), 0.905 (extra effort as leader), 0.838 (effectiveness as a leader) and 0.898 (personal satisfaction with one’s leadership) respectively.

Figure 1. Leadership Domains and Corresponding Questionnaire Items

\begin{tabular}{|c|c|}
\hline Leadership Style & Sample Questions \\
\hline Transformational & $\begin{array}{l}\text { - I talk optimistically about the future } \\
\text { - I talk enthusiastically about what needs to be accomplished } \\
\text { - I go beyond self-interest for the good of the group }\end{array}$ \\
\hline Active transactional & $\begin{array}{l}\text { - I express satisfaction when others meet expectations } \\
\text { - I discuss in specific terms who is responsible for achieving } \\
\text { performance targets } \\
\text { - I provide others with assistance in exchange for their efforts }\end{array}$ \\
\hline Passive transactional & $\begin{array}{l}\text { - I delay responding to urgent questions } \\
\text { - I avoid getting involved when important issues arise } \\
\text { - Is absent when needed }\end{array}$ \\
\hline Extra effort as leader & $\begin{array}{l}\text { - I get others to do more than they expected to do } \\
\text { - I heighten others' desire to succeed }\end{array}$ \\
\hline $\begin{array}{l}\text { Self-perception of one's } \\
\text { effectiveness as a leader }\end{array}$ & $\begin{array}{l}\text { - I am effective in meeting others' job-related needs } \\
\text { - I am effective in representing others to higher authority }\end{array}$ \\
\hline $\begin{array}{l}\text { Satisfaction with one's own } \\
\text { leadership style }\end{array}$ & $\begin{array}{l}\text { - I use methods of leadership that are satisfying } \\
\text { - I work with others in a satisfactory way }\end{array}$ \\
\hline
\end{tabular}

Transformational leadership style scores were derived by averaging all of the scores from the items contained in the Idealized Influence (Attributed), Idealized Influence (Behavior), Inspirational Motivation, Intellectual Stimulation, and Individualized Consideration sub-scales, a total of 20 items. Transactional leadership (active) style scores were derived by averaging all of the scores from the 8 items in the Contingent Reward and Management-by-Exception (Active) sub-scales. Transactional leadership (passive) style scores were derived by averaging all of the scores from the 8 items in the Management-by-Exception (Passive) and Laissez-Faire Leadership sub-scales. Extra effort was derived by averaging the scores of 3 items, self perception of effectiveness was derived by averaging the scores of 4 items, and self satisfaction with leadership was derived by averaging the scores of 2 items. The higher the score on each component scale, the greater was the utilization/incorporation of that style by a leader. Thus, a higher score indicated a preferable (positive) outcome for all domains, except the avoidant transactional leadership style, where the lower score indicated lesser avoidant and passive behavior.

Additionally, demographic characteristics of the administrators (age, gender, race/ethnicity, years as supervisor, current title, years in current position, educational background and agency budget) were also ascertained by the survey. 


\section{Findings}

Frequency distributions were used to explore the demographic characteristics of the respondent pool. To evaluate the impact of sex (a binomial variable) on the leadership domains, an independent sample t-test was conducted. To evaluate the impact of age, years as supervisor and educational background on the six leadership domains being measured, Analysis of Variance (ANOVA) tests were conducted as each of the independent variables (age, years as supervisor and educational background) had multiple categories, and the dependent variables (leadership domains) were measured as continuous variables.

\section{Influence of Administrators' Demographic Characteristics}

The demographic characteristics of sex, race/ethnicity, age, and years as supervisor were tested to evaluate their impact on the three leadership styles (transformational, transactional \{active\} and transactional \{passive\}), as well as the self perceptions of extra effort, one's assessment of effectiveness as a leader, and satisfaction with one's leadership.

With respect to sex, the only leadership style that was found to be statistically significantly different for male and female administrators was charismatic leadership (see Table 2). An independent samples t-test demonstrated that women $(\mathrm{M}=3.38, \mathrm{SD}=0.36)$ were likely to perceive themselves more charismatic than their male counterparts $(\mathrm{M}=3.26, \mathrm{SD}=0.39), \mathrm{t}(381)=-3.15, \mathrm{p}=0.002)$.

Race/ethnicity, age and years as supervisor were found to have no statistically significant relationship to the leadership styles or self perceptions of effectiveness, extra effort and professional satisfaction of administrators.

\section{Influence of Administrators' Educational Backgrounds}

Educational background was measured by asking respondents to highlight the highest degree obtained as well as specifying their major area of study. The educational backgrounds were then collapsed into six major categories - undergraduate (BA/BS), graduate degree in liberal arts or social sciences (MA/MS), graduate social work degree (MSW), graduate business degree (MBA), law degree (JD), and a doctoral degree (PhD). An analysis of variance showed that educational background was significantly related to transformational leadership $\mathrm{F}(5,356)=3.62, \mathrm{p}=0.003$, passive transactional leadership $\mathrm{F}(5,356)=2.76, \mathrm{p}=0.02$, self perception of applying extra effort $\mathrm{F}(5,352)=2.98, \mathrm{p}=$ 0.01 , perception of one's effectiveness as a leader $F(5,352)=2.25, p=0.05$, and satisfaction with one's leadership $\mathrm{F}(5,350)=2.24, \mathrm{p}=0.05$. These findings are presented in Table 3.

The authors would like to caution readers that the differences in scores between administrators from diverse educational backgrounds were relatively small. However, keeping in mind the small differences between most of the educational backgrounds, administrators with a JD seemed to score the lowest on most of the domains of leadership, while administrators with a $\mathrm{PhD}$ scored the highest. Table 3 compares the 
mean scores across leadership domains. With regard to transformational leadership, administrators with a $\mathrm{PhD}(\mathrm{M}=3.42, \mathrm{SD}=0.37)$ were most likely to assess themselves as transformational (charismatic), while administrators with a JD $(\mathrm{M}=2.93, \mathrm{SD}=0.47)$ were least likely to identify themselves as charismatic or inspirational (sub components of transformational leadership). With regard to passive transactional leadership styles, administrators with only an undergraduate degree $(\mathrm{M}=0.84, \mathrm{SD}=0.57)$ were most likely to identify themselves as passive and avoidant while administrators with an MSW ( $(\mathrm{M}=0.61, \mathrm{SD}=0.47)$ were least likely to so identify themselves in this way. Administrators with a $\mathrm{PhD}(\mathrm{M}=3.32, \mathrm{SD}=0.56)$ were most likely to highlight engaging in extra efforts as a leader to enhance employees' functioning, while administrators with a $\mathrm{JD}(\mathrm{M}=2.84, \mathrm{SD}=0.69)$ were least likely. Administrators with a $\mathrm{PhD}(\mathrm{M}=3.51, \mathrm{SD}=0.37)$ were most likely to perceive themselves as effective leaders, while administrators with a JD were the least likely $(\mathrm{M}=3.04, \mathrm{SD}=0.69)$. Finally, administrators with an MSW $(\mathrm{M}=3.42, \quad \mathrm{SD}=0.54)$ were the most satisfied with their own leadership while administrators with a $\mathrm{PhD}$ seemed to be the least satisfied $(\mathrm{M}=2.49, \mathrm{SD}=0.52)$, followed by administrators with a JD $(\mathrm{M}=2.91, \mathrm{SD}=0.62)$

Tukey HSD post hoc tests were conducted to assess the pair-wise differences between the various educational backgrounds. For transformational leadership (charismatic and inspirational), statistically significant differences were observed between administrators with a JD and those with an undergraduate $(\mathrm{p}=0.015)$, graduate MA/MS ( $p=0.003)$, MSW $(p=0.002)$ and PhD $(p=0.001)$ degrees respectively. For passive transactional (avoidant) leadership, statistically significant differences were observed between administrators with an MA/MS and an MSW degree $(\mathrm{p}=0.05)$ only. With reference to applying extra effort as leaders, there were no statistically significant differences between any two groups. For self-perception of effectiveness, statistically significant differences were observed between administrators with a JD and those with an MSW ( $\mathrm{p}=0.04)$, and between administrators with a JD and those with a $\mathrm{PhD}(\mathrm{p}=0.015)$ respectively. Statistically significant differences were observed with respect to satisfaction with one's leadership between administrators with a JD and those with an MSW ( $p=0.04)$ and between administrators with a JD and those with a $\mathrm{PhD}(\mathrm{p}=0.023)$ respectively.

When gender, race/ethnicity, age and years as supervisor (all coded as categorical variables) were added to the model comparing educational backgrounds and leadership styles (using MANOVAs), they did not have a statistically significant impact on the relationship between educational background and leadership styles. 
Table 2. Independent Samples t-test, Means, and Standard Deviations for Leadership Styles and Gender

\begin{tabular}{|c|c|c|c|c|c|c|c|}
\hline Leadership Domains & Sex & $\mathrm{N}$ & $\bar{x}$ & SD & $\mathrm{t}$ & $\mathrm{df}$ & $\mathrm{p}$ \\
\hline Transformational Leadership & $\begin{array}{c}\text { Male } \\
\text { Female }\end{array}$ & $\begin{array}{l}147 \\
236\end{array}$ & $\begin{array}{l}3.26 \\
3.38\end{array}$ & $\begin{array}{l}.39 \\
.36\end{array}$ & -3.15 & 381 & $.002^{* *}$ \\
\hline $\begin{array}{l}\text { Active Transactional } \\
\text { Leadership }\end{array}$ & $\begin{array}{c}\text { Male } \\
\text { Female }\end{array}$ & $\begin{array}{l}147 \\
236\end{array}$ & $\begin{array}{l}2.42 \\
2.45\end{array}$ & $\begin{array}{l}.51 \\
.59\end{array}$ & -.56 & 381 & .571 \\
\hline Passive Transactional Leadership & $\begin{array}{c}\text { Male } \\
\text { Female }\end{array}$ & $\begin{array}{l}147 \\
236\end{array}$ & $\begin{array}{l}0.74 \\
0.70\end{array}$ & $\begin{array}{l}.43 \\
.52\end{array}$ & 0.72 & 381 & .472 \\
\hline Extra effort as leader & $\begin{array}{c}\text { Male } \\
\text { Female }\end{array}$ & $\begin{array}{l}147 \\
236\end{array}$ & $\begin{array}{l}3.16 \\
3.25\end{array}$ & $\begin{array}{l}.55 \\
.57\end{array}$ & -1.54 & 377 & .124 \\
\hline $\begin{array}{l}\text { Perception of one's } \\
\text { effectiveness as leader }\end{array}$ & $\begin{array}{c}\text { Male } \\
\text { Female }\end{array}$ & $\begin{array}{l}147 \\
236\end{array}$ & $\begin{array}{l}3.38 \\
3.45\end{array}$ & $\begin{array}{l}.46 \\
.45\end{array}$ & -1.49 & 377 & .135 \\
\hline $\begin{array}{l}\text { Satisfaction with own } \\
\text { leadership style }\end{array}$ & $\begin{array}{c}\text { Male } \\
\text { Female }\end{array}$ & & & & -- & -- & -- \\
\hline$* \mathrm{p}<0.05, * * \mathrm{p}$ & & & & & & & \\
\hline
\end{tabular}


Table 3. Analysis of Variance (ANOVA) and Mean Scores for Leadership Styles and Educational Background

\begin{tabular}{|c|c|c|c|c|c|c|c|c|c|}
\hline Leadership Domains & & $\begin{array}{l}\text { Educational } \\
\text { Background }\end{array}$ & $\mathrm{n}$ & $\bar{x}$ & SD & $\begin{array}{l}\text { Sum of } \\
\text { Squares }\end{array}$ & $\mathrm{F}$ & $\mathrm{df}$ & $\mathrm{p}$ \\
\hline $\begin{array}{l}\text { Transformational } \\
\text { Leadership }\end{array}$ & $\begin{array}{l}\text { Between Groups } \\
\text { Within Groups } \\
\text { Total }\end{array}$ & $\begin{array}{c}\text { BA/BA } \\
\text { MA/MS } \\
\text { MSW } \\
\text { MBA } \\
\text { JD } \\
\text { PhD }\end{array}$ & $\begin{array}{r}50 \\
108 \\
130 \\
14 \\
13 \\
47\end{array}$ & $\begin{array}{l}3.32 \\
3.35 \\
3.35 \\
3.29 \\
2.93 \\
3.24\end{array}$ & $\begin{array}{l}.37 \\
.37 \\
.36 \\
.36 \\
.48 \\
.37\end{array}$ & $\begin{array}{r}2.50 \\
29.24 \\
51.74\end{array}$ & 3.62 & $\begin{array}{r}5 \\
356 \\
361\end{array}$ & $.003^{* *}$ \\
\hline $\begin{array}{l}\text { Active Transactional } \\
\text { Leadership }\end{array}$ & $\begin{array}{l}\text { Between Groups } \\
\text { Within Groups } \\
\text { Total }\end{array}$ & $\begin{array}{c}\mathrm{BA} / \mathrm{BA} \\
\mathrm{MA} / \mathrm{MS} \\
\mathrm{MSW} \\
\mathrm{MBA} \\
\mathrm{JD} \\
\mathrm{PhD}\end{array}$ & $\begin{array}{r}50 \\
108 \\
130 \\
14 \\
13 \\
47\end{array}$ & $\begin{array}{l}2.35 \\
2.45 \\
2.44 \\
2.55 \\
2.20 \\
2.60\end{array}$ & $\begin{array}{l}.62 \\
.51 \\
.53 \\
.52 \\
.66 \\
.67\end{array}$ & $\begin{array}{r}2.46 \\
112.49 \\
114.95\end{array}$ & 1.56 & $\begin{array}{r}5 \\
356 \\
361\end{array}$ & .171 \\
\hline $\begin{array}{l}\text { Passive } \\
\text { Transactional } \\
\text { Leadership }\end{array}$ & $\begin{array}{l}\text { Between Groups } \\
\text { Within Groups } \\
\text { Total }\end{array}$ & $\begin{array}{c}\text { BA/BA } \\
\text { MA/MS } \\
\text { MSW } \\
\text { MBA } \\
\text { JD } \\
\text { PhD }\end{array}$ & $\begin{array}{r}50 \\
108 \\
130 \\
14 \\
13 \\
47\end{array}$ & $\begin{array}{l}.84 \\
.79 \\
.61 \\
.64 \\
.79 \\
.66\end{array}$ & $\begin{array}{l}.57 \\
.47 \\
.47 \\
.34 \\
.42 \\
.47\end{array}$ & $\begin{array}{r}3.18 \\
81.94 \\
85.12\end{array}$ & 2.77 & $\begin{array}{r}5 \\
356 \\
361\end{array}$ & $.018 *$ \\
\hline Extra effort as leader & $\begin{array}{l}\text { Between Groups } \\
\text { Within Groups } \\
\text { Total }\end{array}$ & $\begin{array}{c}\text { BA/BA } \\
\text { MA/MS } \\
\text { MSW } \\
\text { MBA } \\
\text { JD } \\
\text { PhD }\end{array}$ & $\begin{array}{r}50 \\
108 \\
130 \\
14 \\
13 \\
47\end{array}$ & $\begin{array}{l}3.06 \\
3.31 \\
3.18 \\
3.14 \\
2.84 \\
3.32\end{array}$ & $\begin{array}{l}.59 \\
.56 \\
.55 \\
.28 \\
.69 \\
.56\end{array}$ & $\begin{array}{r}4.62 \\
109.27 \\
113.89\end{array}$ & 2.98 & $\begin{array}{r}5 \\
352 \\
357\end{array}$ & $.012 *$ \\
\hline
\end{tabular}

(continued) 
Table 3 (continued)

\begin{tabular}{|c|c|c|c|c|c|c|c|c|c|}
\hline Leadership Domains & & $\begin{array}{l}\text { Educational } \\
\text { Background }\end{array}$ & $\mathrm{n}$ & $\bar{x}$ & SD & $\begin{array}{l}\text { Sum of } \\
\text { Squares }\end{array}$ & $\mathrm{F}$ & $\mathrm{df}$ & $\mathrm{p}$ \\
\hline \multirow{6}{*}{$\begin{array}{l}\text { Perception of one's } \\
\text { effectiveness as } \\
\text { leader }\end{array}$} & Between Groups & $\mathrm{BA} / \mathrm{BA}$ & 50 & 3.41 & .44 & 2.31 & \multirow[t]{6}{*}{2.25} & 5 & \multirow[t]{6}{*}{$.049 *$} \\
\hline & Within Groups & MA/MS & 108 & 3.41 & .51 & 72.23 & & 352 & \\
\hline & Total & MSW & 130 & 3.43 & .42 & 74.54 & & 357 & \\
\hline & & MBA & 14 & 3.42 & .23 & & & & \\
\hline & & JD & 13 & 3.04 & .69 & & & & \\
\hline & & $\mathrm{PhD}$ & 47 & 3.51 & .37 & & & & \\
\hline \multirow{6}{*}{$\begin{array}{l}\text { Satisfaction with } \\
\text { own } \\
\text { leadership style }\end{array}$} & Between Groups & $\mathrm{BA} / \mathrm{BA}$ & 50 & 3.35 & .52 & 3.28 & \multirow[t]{6}{*}{2.24} & 5 & \multirow[t]{6}{*}{$.050 *$} \\
\hline & Within Groups & MA/MS & 108 & 3.38 & .56 & 102.59 & & 350 & \\
\hline & Total & MSW & 130 & 3.42 & .54 & 105.87 & & 355 & \\
\hline & & MBA & 14 & 3.32 & .42 & & & & \\
\hline & & JD & 13 & 2.91 & .62 & & & & \\
\hline & & $\mathrm{PhD}$ & 47 & 2.49 & .52 & & & & \\
\hline
\end{tabular}




\section{Discussion}

The authors had expected to find a significant difference in leadership styles between those administrators with social work backgrounds and those from other educational backgrounds. Although some statistically significant differences based on educational background were found, those between MSWs and others did not emerge in these data. Nonetheless, four major themes did emerge in this study.

\section{Administrators with a JD were most likely to assess themselves as less effective leaders than their counterparts from other educational disciplines.}

Administrators with a JD comprised barely $7 \%$ of our total sample. This may reflect their low representation in the upper management of social service agencies in our study region. Nevertheless, administrators with a law degree consistently scored low on several components of leadership - transformational, perception of effectiveness as a leader and satisfaction with one's leadership. Since this was a self-assessment, the low scores could be interpreted in a number of ways. One might conclude that administrators with a JD do not perceive themselves as strong in traditional areas of leadership - inspirational, motivational, and transactional. This may be the consequence of a lack of formal training or course opportunities in administration and management while pursuing a law degree. Or it may be a consequence of lawyers simply using a different metric in rating themselves than others in the study. It is also possible that attorneys who currently manage social service agencies may delegate the responsibility of day-to-day management to other professionals, while they focus on the legal and fiscal components of their job.

\section{Administrators with PhD's were most likely to assess themselves as more effective leaders than their counterparts.}

This was a surprising finding. Though the doctoral degrees represented diverse fields of study, the majority were in the fields of social work or public administration. We hypothesized that unlike an MSW degree, which may offer limited opportunities for the study of management, doctoral programs in social work or public administration offer more comprehensive opportunities for education in leadership. One would expect that doctoral programs in public administration would attract students who are specifically interested in pursuing careers in nonprofit management or social service administration. Similarly, doctoral students in social work may perceive the value of a $\mathrm{PhD}$ for career advancement as administrators. This may explain the higher level of self-assessment as leaders among those with the most education in the study. However, it cannot be assumed with a high degree of certainty that the enhanced scores of leadership in this group represent a comprehensive understanding and application of optimal leadership skills/knowledge. It may simply be that these respondents are more attuned to the leadership requirements of the field and provided the answers they believed to be the most appropriate, whether or not they actually applied them in practice. 
3. Administrators with an MSW or MA/MS were most likely to assess themselves higher on transformational leadership skills while being the least likely to be passive avoidant.

Although administrators with an MSW did not score the highest on most of the components of leadership, they were the second highest scorer in the component of transformational leadership, just below administrators with a $\mathrm{PhD}$ (some of which were in social work). It is heartening to know that administrators with a social work background place a premium on transformational leadership - inspirational, motivational and charismatic components. Given the relatively low salaries in the nonprofit world and the significant service and budgetary barriers that are present, administrators need to utilize their transformational skills to attract and retain their workforce, prevent burnout, and enhance service delivery. Research has shown that motivational and charismatic leaders have a positive impact on staff retention and morale (Mary, 2005).

It was also heartening to note, that despite the stereotype of social workers being "soft", the MSW administrators in our sample scored quite low on passive-avoidant leadership styles. This underscores the fact that social work administrators can be just as effective and "tough" as their counterparts from other fields. But it should be noted that the social service administration field may attract a specific personality type among social workers - those who want to and like to lead. While administrators from other fields may also be attracted to administration in social service for similar reasons, we believe that given the propensity of social workers for clinical practice, the few that are attracted to administration and management positions may see their purpose as transformational.

\section{The overall differences in scores on most of the components of leadership between the various cohorts of educational backgrounds were small (although some were statistically significant).}

We believe that the reason we did not see major differences between the various cohorts of administrators is that the human services administration field attracts a specific kind of person - an individual who wants to make a difference, is interested in change and social transformation, and would like to help those who are vulnerable or in need. Thus, personal attributes such as charisma, inspiration, and motivation are inherent traits that are shared by the majority of administrators, irrespective of their educational background or training. This may be the reason for the lack of statistically significant differences between all the academic disciplines in our study.

\section{Limitations}

There are some limitations of this study that may impact the generalizability of the findings. First, since this was a mail survey, self-selection bias reflected in the low response rate may have influenced the findings. A relatively high number of MSW respondents may be due to the authors identifying themselves with social work in the introduction to the survey, thus perhaps eliciting a higher response rate from social workers. 
Second, there were relatively few administrators with an MBA or JD in our study, as compared to administrators with other degrees. Thus power was compromised and there is the possibility of issues of statistical conclusion validity. Third, the selection of the MLQ instrument to assess leadership styles may have limited our ability to understand and interpret leadership in social service organizations. Because this instrument was not specifically designed to assess leadership characteristics of social service administrators, a few important elements critical to leadership in this field may not have been included. For instance, prior social work practice experience that some administrators may possess, the skills and knowledge needed to work with at-risk populations and complex social problems, knowledge of social policy analysis and advocacy, dual roles played by administrators in smaller agencies (direct practice and management), etc., might be additional factors that need to be evaluated. Finally, the MLQ relied on self report and assessment by administrators, thereby introducing the element of social desirability bias or exaggerated self-rating of positive attributes of leadership. Due to financial constraints, we could not include multiple perspectives of leadership style and competence in the study.

\section{Areas of Future Inquiry}

This study only assessed the leadership styles of human service administrators from diverse disciplines and the sample represented a small portion of all leaders in a single geographic region. While the findings confirm that people from various academic disciplines lead social service agencies, it is possible that this type of work attracts people with specific leadership orientations. Further investigation is required to more deeply understand how social work administration students can be trained and supported to take on senior leadership roles. Such questions might include:

- What are the specific challenges faced by administrators in the social service field?

- Do social work administrators believe their academic training prepares them for the challenges of leadership?

- What can social work education at the MSW and PhD levels do to enhance the effectiveness of future administrators?

The question of how social workers can impact leadership at the most senior levels, as well as the appropriateness of social workers for such roles, has been debated for the last twenty years. It is clear given the sample that despite small numbers of social work students entering administration and management tracks, social workers are finding their way to leadership roles. It is our responsibility as educators to help prepare social work students for such roles.

\section{References}

Antonakis, J., Avolio, B. J., \& Sivasubramaniam, N. (2003). Context and leadership: an examination of the nine-factor full-range leadership theory using the Multifactor Leadership Questionnaire, The Leadership Quarterly, 14(3), 261-295. 
Austin, M. J., \& Ezell, M. (2004). Educating future social work administrators. Administration in Social Work, 28(1), 1-3.

Austin, M. J., Regan, K., Samples, M. W., Schwartz, S. L., \& Carnochan, S. (2011). Building managerial and organizational capacity in nonprofit human service organizations through a leadership development program. Administration in Social Work, 35(3), 258-281.

Bass, B. M. (1985). Leadership: Good, better, best. Organizational Dynamics, 13(3), 2640.

Bass, B. M., \& Avolio, B. J. (1990). Multifactor Leadership Questionnaire. Palo Alto, CA: Consulting Psychologists Press.

Bass, B. M., \& Avolio, B. J. (1993). Transformational leadership theory: A response to critiques. In M. M. Chemmers \& R. Ammons (Eds.), Leadership and research: Perspectives and direction (pp. 49-80). San Diego, CA: Academic Press.

Bass, B. M., \& Avolio, B. J. (1994). Improving organizational effectiveness through transformational leadership. Thousand Oaks, CA: Sage Publications.

Bass, B. M., \& Avolio, B. J. (2000). MLQ: Multifactor questionnaire: Third edition manual and sampler set. Redwood City, CA: Mind Garden.

Bass, B. M., Avolio, B. J., \& Atwater, L. (1996). The transformational and transactional leadership of men and women. Applied Psychology, 45(1), 5-34.

Bell, J., Moyers, R., \& Wolfred, T. (2006). Daring to lead 2006: A national study of nonprofit executive leadership. San Francisco, CA, San José, CA, Washington, DC: CompassPoint Nonprofit Services and The Meyer Foundation.

Birdsell, D. S., \& Muzzio, D. (2003). The next leaders: UWNYC grantee leadership development and succession management needs. New York, NY: United Way of New York City and Baruch College School of Public Affairs.

Cornelius, M., Moyers, R., \& Bell, J. (2011). Daring to lead 2011: A national study of nonprofit executive leadership. San Francisco, CA: CompassPoint Nonprofit Services and the Meyer Foundation.

Daft, R. L. (1999). Leadership: Theory and practice. Orlando, FL: Harcourt Brace \& Company.

Edwards, R. L., Cooke, R. W., \& Reid, P. N. (1996). Social work management in an era of diminishing federal responsibility. Social Work, 41(5), 468-479.

Ezell, M., Chernesky, R., \& Healy, L. (2004). The learning climate for administration students. Administration in Social Work, 28(1), 57-76.

Gellis, Z. D. (2001). Social work perceptions of transformational and transactional leadership in health care. Social Work Research, 25(1), 17-25.

Gose, B. (2004). Charities pay women less than men, study finds. Chronicle of Philanthropy, 17(3), p. 40. 
Hoefer, R. (2003). Administrative skills and degrees: The 'best place' debate rages on. Administration in Social Work, 27(1), 25-46.

Hopkins, K., \& Hyde, C. (2002). The human service managerial dilemma: New expectations, chronic challenges and old solutions. Administration in Social Work, 26(3), 1-15.

Hrywna, M. (2006, February 1). Women catching up with men, but neither with inflation. The Non-profit Times, 20(3), 23-25.

Hunt, J. G., 1999. Transformational/charismatic leadership’s transformation of the field: An historical essay. Leadership Quarterly, 10(2), 129-144.

Joslyn, H. (2003). Charity’s glass ceiling. Chronicle of Philanthropy, 15(11), p. 47.

Jung, D. I., \& Avolio, B. J. (2000). Opening the black box: An experimental investigation of the mediating effects of trust and value congruence on transformational and transactional leadership. Journal of Organizational Behavior, 21(8), 949-964.

Khan, M. J., Aslam, N., \& Riaz, M. N. (2012). Leadership styles as predictors of innovative work behavior. Pakistan Journal of Social and Clinical Psychology, 9(2), $17-22$.

Knee, R. T., \& Folsom, J. (2012). Bridging the crevasse between direct practice social work and management by increasing the transferability of core skills. Administration in Social Work, 36(4), 390-408.

Lipman, H. (2006). Pay gap narrows for male and female nonprofit executives, study finds. Chronicle of Philanthropy 19(1), p. 13.

Long, D. D., \& Shobe, M. A. (2010): Lessons learned from preparing social workers for grant writing via connected learning. Administration in Social Work, 34(5), 392-404.

Lowe, K. B., Kroeck, K. G., \& Sivasubramaniam, N. (1996). Effectiveness correlates of transformational and transactional leadership: A meta-analytic review of the MLQ literature. The Leadership Quarterly, 7(3), 385-425.

Mary, N. L. (2005). Transformational leadership in human service organizations. Administration in Social Work, 29(2), 105-118.

McNutt, J. G. (1995). The macro practice curriculm in graduate social work education: Results of a national study. Administration in Social Work, 19(3), 59-74.

Menefee, D. (2009). What human services managers do and why they do it. In R. Patti (Ed.), The handbook of human services management ( $2^{\text {nd }}$ ed., pp. 101-116). Thousand Oaks, CA: Sage Publications.

Mizrahi, T., \& Berger, C. S. (2005). A longitudinal look at social work leadership in hospitals: The impact of a changing health care system. Health Social Work, 30(2), 155-165.

National Association of Social Workers. (2009). Social work: Purpose and possibility. Retrieved from 
http://www.naswdc.org/pressroom/swMonth/2009/documents/swmonthtoolkit2009.p df

National Center for Charitable Statistics. (2011, February 1). National taxonomy of exempt entities. Retrieved from http://nccs.urban.org/classification/NTEE.cfm

Neugeboren, B. G. (1986). Systemic barriers to education in social work administration. Administration in Social Work, 10(2), 1-14.

Nesoff, I. (2007). The importance of revitalizing management education for social workers. Social Work, 52(3), 283-285.

O’Leary, A. M. (2009, February 4). Lilly Ledbetter Fair Pay Act won’t close wage gap between men and women. San Francisco Chronicle, p. A-13. Retrieved from http://www.sfgate.com/opinion/article/Lilly-Ledbetter-Fair-Pay-Act-won-t-closewage-gap-3173996.php

Patti, R. J. (1987). Managing for service effectiveness in social welfare organizations. Social Work, 32(5), 377-381.

Richardson, R. F. (2010). 360-degree feedback: Integrating Business know-how with social work values. Administration in Social Work, 34(3), 259-274.

Roeger, K. L., Blackwood, A., \& Pettijohn, S. L. (2011). The nonprofit sector in brief: Public charities, giving and volunteering, 2011. Washington, DC: Urban Institute.

Sherlock, M. F., \& Gravelle, J. G. (2009). An overview of the nonprofit and charitable sector (CRS Report for Congress 7-5700 ed.). Washington DC: Congressional Research Office.

Social Work Congress (2010). Social work imperatives for the next decade. Washington DC: NASW Press. Retrieved from http://www.naswdc.org/2010congress/documents/2010Imperatives.pdf

Suarez, D. F. (2010). Street credentials and management backgrounds: Careers of nonprofit executives in an evolving sector. Nonprofit and Voluntary Sector Quarterly, 39(4), 696-716.

Teegarden, P. (2004). Nonprofit executive leadership and transitions survey, 2004. Silver Spring, MD: Managance Consulting.

United Neighborhood Houses. (2012). Our members. New York, NY: Author. Retrieved from http://www.unhny.org/our_members/members_all

Wilson, S., \& Lau, B. (2011). Preparing tomorrow’s leaders and administrators: Evaluating a course in social work management. Administration in Social Work, 35(3), 324-342.

Wimpfheimer, S. (2004). Leadership and management competencies defined by practicing social work managers. Administration in Social Work, 28(1), 45-56. 
Wuenschel, P. C. (2006). The diminishing role of social work administrators in social service agencies: Issues for consideration. Administration in Social Work, 30(4), 1518.

Yukl, G. (1999). An evaluation of conceptual weaknesses in transformational and charismatic leadership theories. The Leadership Quarterly, 10, 285-305.

\section{Author note:}

Address correspondence to: Dr. Lauri Goldkind, LMSW, PhD, Assistant Professor, Graduate School of Social Service, Fordham University, 113 West $60^{\text {th }}$ Street, Rm. 721A, New York, NY 10023. Email: goldkind@fordham.edu 